\title{
The Pragmatic and Stylistic Aspects of Communication Between State Authorities and the Citizen within e-Administration in Poland
}

\author{
Joanna Kowalczyk ${ }^{1}$ (1)
}

Accepted: 4 November 2020 / Published online: 17 November 2020

(c) The Author(s) 2020

\begin{abstract}
This article discusses the specificity of remote communication between state authorities and citizens as part of e-administration services. Attention was paid to the available technological tools used in state-citizen communication (e.g. applications, help centres), but most of all, the focus was on the pragmatics of creating messages in the "digital office". The aim of the present study was to identify the main linguistic and quasi-linguistic instruments that build the stylistic and pragmatic formula of e-administration in Poland. The source material was taken from the widely available and most popular e-administration platforms, containing detailed information on services provided by public administration and enabling the citizen to establish remote contact with the state, such as Obywatel.gov.pl, ePUAP.gov.pl, CEIDG.gov. pl and Biznes.gov.pl.
\end{abstract}

Keywords e-Administration $\cdot$ Language style $\cdot$ State $\cdot$ Citizen

\section{Introduction}

In a globalised society focused on practicality, access to information constitutes one of the main factors determining the efficient functioning of a group. The speed and ease of obtaining information are the main criteria for assessing the suitability of the most common sources of knowledge. The development of digitalisation enabled the adjustment of traditional competence-shaping tools to the needs of the constantly developing "Internet civilization" [19]. Also, the sources of legal and official knowledge have been transferred to electronic public administration platforms (e-administration).

Joanna Kowalczyk

joanna.kowalczyk@ujk.edu.pl

1 Jan Kochanowski University in Kielce, Kielce, Poland 
The present paper discusses a reflexive relation between the changing social reality and the legal information resources available on e-administration platforms in Poland. More specifically, the object for discussion will involve teleology of expression and ways of communication which act as a multimedia link between the state and the citizen. It has to be stressed that the term state as used in the paper is not identified with political institutions but rather state public authorities, which operate as executive units constituting the administrative organisation of society. Consequently, the term state shall be treated as a system which legally regulates relevant relations within the community; the very communication of the state with the citizens is not based on facts considered adequate for the assumptions of normative acts and/or individual and specific documents in force.

The aim of the present study was to distinguish the main linguistic and quasilinguistic (iconic, graphic) instruments which create a pragmatic and stylistic formula of e-administration in Poland, as well as proving that the official legal message issued by public authorities is not inextricably linked with the formalistic method of text building.

The pragmatic-stylistic criterion was used as the methodological basis of the study [21, 22]. The adopted perspective allowed for defining the communicative functionality of the analysed content by taking into account the context of the semiotic network covering, on the one hand, the goals of the sender, recipient and transmission channel, and on the other-a set of linguistic means, which are the preferred method of creating messages within e-administration services.

The corpus has been collected from official services containing detailed information about the platforms provided by public administration bodies and intended to interactively communicate with citizens (Obywatel.gov.pl, ePUAP.gov.pl, CEIDG. gov.pl and Biznes.gov.pl).

The article first presents the complexity of standard communication between the state and the citizen, in which a formalised language code is used that is often incompatible with general language. Then, attention was drawn to the dynamics of current social trends, which make members of developed communities expect the state to provide them with digital sources of information which will give them unlimited and quick access. Next, e-administration in Poland was characterised as an invaluable source of accessible legal information as a response to ubiquitous and ongoing digitisation. Against this background, various communication procedures used by the institutional sender, which improve its image and encourage contact within e-administration as a better, simpler and faster option than direct contact, are discussed in the following sections.

\section{Specificity of Traditional Official Communication}

In order to give the right context to the discussed research problem, one should start with outlining the specificity of official discourse in the traditional version, i.e. based on direct relations between a citizen and an official or in the form of paper correspondence. This will constitute the right background to capture the dissonance between the quality of traditional communication and e-government communication. 
Official communication in its traditional form is based both on normative principles of discourse and on practices developed during interactions. The official nature of this type of communication means that the participants are obliged to comply with rules governing the public sphere. One of the requirements includes the ability to use the correct terminology creating the semantics of official texts. In specialist areas of communication (official, legal, political, etc.), such an ability becomes indispensable for effective functioning so in this respect it is of primary value. Communication skills, enabling the selection of proper terminology to describe a legal fact, have a direct impact on the efficacy of the discourse [cf.: 9]. In order to establish a lasting relation bettween communication skills and the effectiveness of undertaken activities, each participant of an official interaction must use the relevant terms, appropriate for a specific legal category and for understanding their meaning (cf.: legal sentences: Ignorantia iuris nocet, Ignorantia legis non excusat).

Official terminology is a special type of language code which describes extralinguistic reality in a formalised way, frequently inappropriate to the general language [cf.: 1,20]. As a nomenclature created in order to formally conceptualise various phenomena, events, things and persons, it has the potential to refer them to the legally relevant categories (e.g. civil contract, crime, attestation of untruth) and to confer on them different statuses (e.g. the status of the victim, the status of the witness or legal disability status). As a tool for naming and assigning meanings in the context of official communication, it is a form of action.

Participating in official discourse requires both professional and non-professional participants to comply with a formal style of communication with particular emphasis on the appropriate use of legal terms as in this context they are instruments used to achieve intended goals. There is, therefore, the need for precise coding and decoding of the message content and for eliminating potential errors resulting from colloquial understanding of official texts. For instance, confusing similar terms (legal capacity versus capacity to perform act in law; cassation versus cassation appeal) or assigning colloquial meanings to legal terms (building (common meaning) versus building/structure (legal meaning); possession (common meaning) versus possession (legal meaning).

The pragmatic essence of the efficient use of the administrative code lies in the possibility of creating an extra-linguistic reality, which as part of the official discourse ceases to refer to the abstract and potential recipient and instead becomes a tool of performing actions by certain people (officials and office customers). On the basis of the office-citizen communication, legislative assumptions gain a driving force and enable solving individual problems applying general norms. The specific character of the official code has a close connection with the practical and rationalised nature of the institutional discourse. Activities (actions and reactions) as well as speech acts included in the administrative interaction have the status of an intermediate tool (e.g. requests or motions) or a direct impact on the interlocutor (e.g. prohibitions or injunctions). They may also become an instrument of shaping factual and legal (formal and procedural) reality. For this reason, universal and unlimited access to sources of legal knowledge has become a determinant for creating a civil society, which is undoubtedly facilitated by technological progress resulting in the 
most modern digital tools, enabling citizens to handle official matters remotely and to adapt to current communication trends.

\section{E-Administration as a Result of Social and Technological Developments}

Promoting an active lifestyle, creativity and entrepreneurship among citizens means that democratic societies are continuously modelling the image of the self-sufficient citizen [cf.: 14]. Know-how, edutainment and information have become universal values [cf.: 11, 16]. On the basis of these ideas, the electronic system of public services, i.e. e-administration, was created. Within its framework, citizens can remotely, quickly and effectively exercise their rights and fulfil their obligations. In the present article, the term $e$-administration will be discussed based on the assumptions presented by Helene Michel. The researcher distinguished between the synonymous terms: e-administration, e-government, and e-governance. According to Helene Michel's assumptions, e-administration is a model in which the citizen is a "consumer of rights" and demands from the authorities the efficient performance of public services. The authorities in this model are focused on fulfilling the satisfaction of citizens who use the services offered. E-government is a model that assumes little activity of citizens who respond primarily to impulses from authorities. In the e-governance model, the citizen is seen as a source of ideas that can help improve public administration [10]. Taking into account the indicated distinction, it was concluded that in Polish political and social conditions, e-administration is ideologically similar to e-administration presented by Helene Michel, but also draws on the assumptions of e-governance. On the one hand, in the Polish e-administration model, the citizen is treated as a client of the office, who is offered the highest quality of service and is given access to up-to-date legal information. At the same time, the authorities are open to the grassroots initiatives of citizens.

The dynamics of social trends, based on skills, competences and fast access to power, has determined the level and scope of the expectations of community members as regards available information in e-administration systems. By providing citizens with a permanently available source of affirmed information, the state satisfies one of the basic needs of the modern citizen — namely the security of unlimited access to legal information $[15,17]$. People, documents and procedures get digital equivalents, i.e. mobile applications (citizen vs. mCitizen; documents vs. mDocuments; verification vs. mVerification).

Creating and operating e-administration platforms also plays a special educational role and is an effective tool enabling citizens to solve legal or administrative problems independently [18]. E-administration performs the function of the media and creates an official discursive zone as a constituted practice of obtaining legal information and a form of conscious interaction between the state and the citizen.

The presence of official-legal discourse in electronic media means that it gains an additional characteristic feature, namely a public nature. The public attribute favours infotainmentization [2] of communication, i.e. providing official, legal information in an accessible, interesting or even funny way. The infotainmentization of official 
discourse coupled with the effect of liquid modernity replaces restrictive formal conventionality, reification of relations and sustainability of specific patterns of behaviour. Legal discourse in this dimension is characterised by the use of sophisticated and non-conventional linguistic, extra-linguistic and graphic means, which are also relevant for bodies acting in a judicial, executive or legislative capacity.

This form of contact is preferred at Obywatel.gov.pl, ePUAP.gov.pl, CEIDG.gov. $p l$ and Biznes.gov.pl services, where the conscious institutional participant of communication provides the citizens with information in the form of a dynamic and attractive object of consumption received by the interlocutor, not only in the form of a logical reflection, but also through intuitive, emotional and aesthetic perception.

\section{Creating the Image of e-Administration}

Activities which take the form of legal information or actual activities are characterised by formal, or even formalistic structure. However, it is worth paying attention to those elements of the process of communication between the state and the citizen which differ from the bureaucratic and unemotional convention of legal-administrative discourse.

Internet portals are the answer to ubiquitous and ever progressive digitalisation [cf.: 13]. Digitisation in relation to this issue relates to the dissemination and popularisation of electronic infrastructure, which transfers traditional tools (paper documents) to ICT systems and enables the citizen to deal with official matters remotely via the Internet. Additionally, there is no need to appear in person at the office to which we have been assigned, and this constitutes an important element in favour of e-administration. In the era of globalisation, distance or frequent changes of place of residence should not constitute a barrier to exercising administrative rights or to performing administrative duties [6].

Telecommunication services encourage customers to use them, not only because they provide citizens with access to current legal information, but also because they create an interactive office in which, with significant economisation of time, one can perform administrative tasks corresponding to those performed in person at the office or by e-mail. Ubaldo Comite rightly claims that e-Administration "consists of a strategic instrument for reformulating the organisation and the operation of Public Administrations, acting as a catalyst of trends and changes. It not only represents a resource that allows economic and operational advantages to be obtained, but is also an instrument that is capable of modifying the pre-existing operational mechanisms of the organization, guaranteeing a fast adaptation to continuous changes in the external environment" [5: 1648].

E-administration also differs from the typical public image of state bodies. The graphics and language design of e-administration platforms take into account the assumptions of the sender-receiver model of expectations and outcomes of official interaction. The information contained therein is directed to the potential recipient, however, the way of expression assumes the form of a personalised statement. The convention of the analysed service portals complies with the infotainment projects 
which combine information with interesting and entertaining form of its transmission [7: 45].

E-administration platforms are colourful and full of iconic signs combined with headings referring to specific issues. They are based on the banner-poster form of transmitting information. Messages are concise and form specific slogans designed to induce the site visitor to focus on the essential, from the point of view of the sender, content (Change the registration information; Suspend economic activity; In the left menu, select which application you want to submit [23]). Therefore, taking into account their form, e-administration platforms do not differ from commercial, success-oriented websites. Visually and linguistically they resemble portals focused on achieving commercial success, so they are conducive to changing the formal way of communicating with the citizen into a less formal one. One has to agree with Piotr Cieciura, who argues that each advertising process is accompanied by a top-down designed qualitative algorithm, which is a measure of the effectiveness of promotional activities [3: 204]. In this case, the success refers to a citizen making a specific choice (e.g. to use an electronic form to make contact with public administration institutions or to download a promoted application). The key to successful content is to give citizens what they need, i.e. information that is simple and easy to understandable. It is also worth mentioning the Plain Language [cf.: 4] movement here. It is an initiative established in order to simplify communication. In Poland, the need for general changes in official communication was signalled in 2010 by the Ministry of Regional Development. The postulates of eliminating hermetic terminology and legal jargon from official texts were disseminated two years later, in 2012, thanks to the popular campaign entitled "Official language friendly to citizens" [12]. The influence of the Plain Language movement is also visible in Polish e-administration. An institutional sender on e-administration platforms makes sure that the messages are understandable, simple, and do not raise any interpretation doubts. In this way, it creates the image of a friendly and caring entity.

\section{Linguistic Style of Messages on e-Administration Platforms}

The linguistic context of the studied Internet services were formulated in such a way as to effectively influence citizens' decisions. To this end, a variety of communicative operations were applied. The first step was to convince the recipient of the superiority of an Internet contact over direct communication in a given office or indirect telephone communication. Thus, the first key advantage of an e-administration platform involves excluding intermediaries and consequently shortening the time-space path between the office and the citizen, cf.:

- Deal with administrative formalities over the Internet (Pl. Załatwiaj sprawy urzędowe przez internet) [27];

- We describe in a simple and accessible way what you need to do, what you need to prepare, and where you need to go without leaving home, needlessly spending time. (Pl. Opisujemy w prosty i przystępny sposób, co musisz zrobić, 
co przygotować, gdzie pójść, a co możesz załatwić bez wychodzenia z domu. Wszystko po to, abyś nie tracił czasu) [29];

- We are currently taking measures to include more descriptions so that you can deal with more formalities over the Internet (Pl. Pracujemy nad tym, by opisów było coraz więcej i abyś więcej spraw mógł załatwić przez internet) [29].

Another key issue is making continuous efforts to simplify messages in the process of finding all the necessary detailed information. The main categories on the e-administration platforms have been identified and categorised. They were also grouped according to the semantic criterion and marked with headings ( $E d u$ cation; Health; Telecommunications etc.). Some of them were illustrated with graphic icons referring directly to the legal area concerned. The platforms also use specific communication strategies, e.g. question-answer strategy: Do you want to check if the bus your children will take on a trip is safe? Use the Safe Bus application/Pl. Chcesz sprawdzić czy autokar, którym twoje dzieci pojada na wycieczkę, jest bezpieczny? Skorzystaj z ustugi Bezpieczny Autobus [30] or writing in the first person: I need to know how to start my own business/Pl. Chce sie dowiedzieć, jak założyć wtasna firme [34].

The analysed platforms consist mainly of such "blocks," indicating both in a graphic and linguistic way, which administrative or legal issues they refer to. By clicking on the appropriate link, citizen obtains all the necessary information which can then be accessed from one place. There is no need for the user to independently search for information that will help them obtain the data required to exercise their rights or fulfil their obligations. The e-administration platforms provide information on whether the citizen is required or authorised to perform certain legal actions, and if so, there are also guidelines contained on what to do in order to obtain a benefit or fulfil certain obligations [7: 46].

In a sense, the citizen becomes the customer who is told what is best for them and what they should do - step by step (Prepare, download and print the application [35]). The regulation of social relations has been transferred from restrictive executive procedures to implementing the strategy of the management of one's rights and obligations. Thus, the command and control function has assumed the form of desiderata. The supplicant becomes the customer and/or the user as evidenced by the bookmarks such as: myGOV, User Panel [28]; Customer Zone [27], My account [35]. The office, in turn, becomes the service provider and the official-administrative context of multimedia communication treats the citizen as an entity which may create reality: Submit Remarks [27]; Submit an idea [32]. On the one hand, state bodies indicate the possibilities of taking action and, on the other, they offer opportunities for engaging in public consultations. This is a new form of communication and cooperation between public administration bodies and citizens.

The state wants to also be accepted and liked and at the same time it requires the satisfaction to be assessed, not on its own merits, but emotionally in the form of an evaluation, as evidenced by the following methods: 


\section{Was this page useful?}

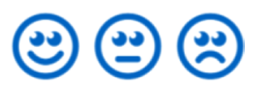

Source: Biznes.gov.pl [31]

\section{Rate: $\star \star \star \star \star$}

Source: CEIDG.gov.pl [24]

The implementation of unconventional communicative solutions by online information carriers may help public authorities create a modern image corresponding to the innovative vision of a successful state. It should be concluded that the style of communication in the analysed communication area is flexible. The form of expression becomes a supporting element of the act of communication. In turn, the activities of the state, aimed at adapting their language to the current social trends, are not only a response to the demands of continuous technical progress but also a reaction towards cultural changes.

\section{Pragmatics of Messages on e-Administration Platforms}

Analysis of the content of e-administration platforms from a pragmatic point of view allowed for the definition of basic ways of influencing the recipient, such as advertising, recommendations, persuasion, encouragement or providing assistance.

E-administration platforms, such as commercial websites, rely on eye-catching banners. It is not a direct message that informs about a certain administration service, but instead an attention-grabbing and persuasive piece of information transmitted in an attractive form. Attractive graphics encourages users to read the content. Simple and understandable content assures people that using the service is also not complicated. The purpose of such an action is to convince the recipient that the offered product (as an administration service actually becomes a product) is beneficial and worth having (must-have), cf.:

- Internet Patient Account - LEARN MORE (Pl. Internetowe Konto Pacjenta DOWIEDZ SIĘ WIĘCEJ) [28];

- Login.gov.pl enables you to log in to multiple public administration websites in Poland [35].

The state (as a company/organisation), apart from advertising its services, directly recommends specific products. E-administration platforms include direct recommendations relating to services that can be of interest to a potential recipient. The service provider directly informs about the improved digital tools and the 
introduction of new services, actively encouraging the recipients to learn about the current offers:

- We fully recommend the services (Pl. Polecamy usługi) [28];

- Take a look at our latest updates section (Pl. Zachęcamy do odwiedzania zakładki Aktualności) [27];

- Recent services (Pl. Najnowsze usługi) [27].

The bodies of public administration on e-administration platforms activate citizens encouraging them to use of the opportunities offered by digital products. The adopted convention of addressing citizens takes the form of mobilising them to take action (do it!) following a command put forward on a given webs

- Download free application (Pl. Pobierz bezpłatną aplikację) [27];

- Set up trusted profile (Pl. Załóż profil zaufany) [28];

- Check if your passport is ready (Pl. Sprawdź, czy twój paszport jest gotowy) [28].

Another way of attracting the recipient's attention is to indicate the advantages of available products and services (free; without leaving home). This form of activity of public administration becomes a project which belongs to the convention awareness of needs and satisfaction of needs (I need free services - I get free services; I need an electronic ID - I get mDocuments etc.), e.g.:

- A Trusted Profile is your free tool that allows you to log in and use an electronic signature, thanks to which you can settle certain official matters online using public administration websites without leaving home (Pl. Profil Zaufany to Twoje darmowe narzędzie, które umożliwia m.in. logowanie i składanie podpisu elektronicznego, dzięki któremu można załatwiać, określone sprawy urzędowe online, w serwisach administracji publicznej, bez wychodzenia z domu) [27].

E-administration platforms have also been adapted to provide solutions for the most frequent administrative and legal problems. They are the source of essential information and provide assistance in cases of doubt. The portals in question include sections on the most frequently asked questions and answers. Some of them [25, 33] offer a Help Centre in the form of an interactive official, operating 24/7. All the information and electronic services are available in Polish and English. The Help Centre is adapted for deaf people. It should be noted that such a virtual consultant is always given a name and there is also an image of his/her face presented on the website; AI has been anthropomorphised to imitate a real official (it is an avatar of a real official) with whom one can chat in real time. This procedure not only reduces the barrier between the office and the citizen, creating the illusion of a real conversation, but in form resembles instant messaging, e.g.:

- Help Center / Linda - Virtual Officer

- Linda Welcome to the Entrepreneur Help Centre. 
- Select a topic from the list or ask me a question.

- You Is registration in CEIDG free of charge?

- Linda All activities related to the entry in the Central Register and Information on Economic Activity (CEIDG) are operated by the Ministry of Economic Development of the Republic of Poland [26].

It should be noted that the Internet is the best place for enabling the use of nonconventional tools. In the process of direct communication between the office and the citizen, it is not acceptable to break free of formal norms. The free use of register or familiar forms of address and politeness, situating the recipient in an informal role, is inappropriate. In contrast, through e-portals, the state institutions may shorten the distance between themselves and the citizen without compromising the status of the office since online communication favours less formal behaviour. The citizen ceases to be a reified entity assigned to a case number. Verbal constructs place the sender and the recipient within the same community, the shape of which depends on jointly undertaken measures aimed at its development, cf.:

- Each case to be settled in an office is treated as a service rendered for you (Pl. Każdą sprawę, którą chcesz załatwić w urzędzie, traktujemy jak usługę, którą wykonujemy dla Ciebie) [28].

On the basis of the above examples it may be concluded that in digital discourse involving public administration there is a change from an official level of communication to a colloquial one; this naturally places the state in the position of not only a protector but also a partner. The state presents its structures as acceptable, appropriate and desirable. Digital systems of communication between the citizen and state administration provide the former with a unique opportunity to exercise rights and fulfil obligations. The multimedia nature of such communication, the casual form of the communication and the availability of the offered services, not restricted by office hours, facilitate the development of another, more modern image of state authorities, thereby creating an online vision of administration which is seen as innovative, caring and supporting.

\section{Conclusions}

In the current socio-political situation, the state as a system wants to promote its services [cf.: 8]. Even in strongly conventional areas which use fossilised instruments, fixed patterns may be and are modified. Such a situation occurs as a result of a change of place of discourse or the information carrier. E-administration platforms, which are an electronic means of communication between the citizen and public administration institutions, promote the transformation of the communication style from the formal to the informal. Therefore, the image of the official style used in official statements and fixed in the minds of language users is subordinated to a more modern, digital form of communication. This means that the activities of state 
bodies become part of the trend of using the style imposed by the standards of our globalised and electronic reality.

The analysis conducted in the present article has shown that e-administration is a unique form of interaction between the office and the citizen. This uniqueness is discernible on many levels. Firstly: the citizen is treated as a client of the office who should be offered the highest quality services and provided with up-to-date legal information. In turn, public administration services become products that are advertised and recommended, and the citizen, as a customer, is encouraged to use them. Within e-administration, the office-citizen relationship becomes a horizontal, collaborative relationship.

The rigid division into subordinate and superior subjects is practically eliminated-at least on a linguistic level. Secondly, the visual side of e-administration platforms differs from the image of the ossified office. A friendly graphic design, characterised by vivid colours, iconic signs, eye-catching posters, drawings or photos undoubtedly encourages the use of administrative services over the Internet. Thirdly: e-administration is a source of advanced technological tools that citizens can use on a daily basis. Citizens have the opportunity to talk to a virtual official or use various applications (including applications that replace identity documents). Fourthly: the style of messages on e-administration platforms is accessible and interesting, therefore it can be called infotainment - providing information in an attractive way.

All these elements build a modern image of public administration bodies that have adapted their way of communicating with citizens to the changing standards. E-administration is an example that dealing with official matters via the Internet can be efficient, rewarding and even interesting.

Open Access This article is licensed under a Creative Commons Attribution 4.0 International License, which permits use, sharing, adaptation, distribution and reproduction in any medium or format, as long as you give appropriate credit to the original author(s) and the source, provide a link to the Creative Commons licence, and indicate if changes were made. The images or other third party material in this article are included in the article's Creative Commons licence, unless indicated otherwise in a credit line to the material. If material is not included in the article's Creative Commons licence and your intended use is not permitted by statutory regulation or exceeds the permitted use, you will need to obtain permission directly from the copyright holder. To view a copy of this licence, visit http://creativecommons.org/licen ses/by/4.0/.

\section{References}

1. Bartmiński, Jerzy. 1992. Styl potoczny. In Język a kultura. Potoczność w języku i kulturze, eds. Janusz Anusiewicz and Franciszek Nieckula, 37-54. Wrocław: Wiedza o Kulturze.

2. Chepornyuk, Anastasiya. 2018. Infotainment as media communication neo-genre: functional and stylistic analysis. Current issues of Ukrainian linguistics: theory and practice 37: 124-140. https:// doi.org/10.17721/APULTP.2018.37.124-140.

3. Cieciura, Piotr. 2009. Reklama a style funkcjonalne języka Zarys problematyki. Bohemistyka 9 (3): 204-212.

4. Clauss, Hannah. 2020. The History of The Plain Language Movement and Legal Language and an Analysis of US Nuclear Treaty Language. https://race.tennessee.edu/cgi/viewcontent.cgi?artic le=3392\&context=utk_chanhonoproj. Accesed 28 September 2020. 
5. Comite, Ubaldo. 2014. E-government and innovation in Italian Public Administration: A business approach. International Journal Of Management \& Information Technology 9 (2): 1648-1661. https ://doi.org/10.24297/ijmit.v9i2.2899.

6. Kasprzyk, Beata. 2018. E-administration Digital Services in Poland. Nierówności Społeczne a Wzrost Gospodarczy 53: 308-319.

7. Kowalczyk, Joanna. 2017. Komunikowanie w dyskursie administracyjnym na platformach internetowych, eds. E. Kołodziejek and R. Sidorowicz. In Internet jako przedmiot badań jezzykoznawczych, 43-55. Szczecin: Wydawnictwo Uniwersytetu Szczecińskiego.

8. Krawczyk, Dariusz. 2018. Zarządzanie polityką informacyjną organizacji w aspekcie komunikacyjnym i wizerunkowym. Zeszyty Naukowe Politechniki Ślaskiej (Organizacja i Zarzqdzanie) 132: 371-380.

9. Malinowska, Ewa. 2001. Wypowiedzi administracyjne. Struktura i pragmatyka. Opole: Wydawnictwo Uniwersytetu Opolskiego.

10. Michel, Hélène. 2005. e-Administration, e-Government, e-Governance and the Learning City: A typology of Citizenship management using ICTs. The Electronic Journal of e-Government 3 (4): 213-218.

11. Ożóg, Marcin. Know-how: pojęcie, zakres ochrony, sposoby udostępniania. https://www.kopipol.pl/ wp-content/uploads/2018/02/Know-how.pdf. Accesed 28 Sept 2020.

12. Piekot Tomasz, Zarzeczny Grzegorz, and Moroń Ewelina. Standard 'plain language' w polskiej sferze publicznej, eds. M. Zaśko-Zielińska and K. Kredens. In Lingwistyka kryminalistyczna. Teoria i praktyka, 197-214. Wrocław: Quaestio.

13. Pieriegud, Jana. 2016. Cyfryzacja gospodarki i społeczeństwa - wymiar globalny, europejski i krajowy, eds. J. Gajewski, W. Paprocki, and J. Pieriegud. In Cyfryzacja gospodarki i społeczeństwa - szanse $i$ wyzwania dla sektorów infrastrukturalnych, 11-37. Gdańsk: Instytut Badań nad Gospodarką Rynkową - Gdańska Akademia Bankowa.

14. Program Aktywni Obywatele. https://aktywniobywatele.org.pl/. Accesed 28 Sept 2020.

15. Radu, Ana-Maria., and Pólkowski. Zdzisław. 2014. Theoretical, technical and practical aspects of e-administration. Zeszyty Naukowe DWSPiT Studia z Nauk Społecznych 7: 185-210.

16. Joey, Reagan, and Lee Moon. 2007. Online technology, edutainment and infotainment. In Communication Technology and Social Change. Theory and Implications, ed. C. Lin and D. Atkin. New York: Routledge.

17. Świątek, W.ładysław. 2019. Development of E-administration Services in Poland. Scientific Journal of Bielsko-Biala School of Finance and Law 3: 72-83.

18. Prada, Torres, Royo Sonia Lourdes, and Pina Vicente. 2005. E-government and the transformation of public administrations in EU countries: Beyond NPM or just a second wave of reforms? Online Information Review 29 (5): 1-33. https://doi.org/10.1108/14684520510628918.

19. Urbański, Andrzej. 2003. Cywilizacja Internetu. Poznań: Nakom.

20. Wilkoń, Aleksander. 2000. Typologia odmian językowych współczesnej polszczyzny. Katowice: Wydawnictwo Uniwersytetu Śląskiego.

21. Witosz, Bo.żena. 2001. Stylistyka a pragmatyka. Katowice: Wydawnictwo Uniwersytetu Śląskiego.

22. Zdunkiewicz-Jedynak, Dorota. 2013. Wykłady ze stylistyki. Warszawa: PWN.

\section{Source materials}

23. Centralna Ewidencja i Informacja o Działalności Gospodarczej. https://prod.ceidg.gov.pl/CEIDG/ CEIDG.Public.UI/DecisionAdditionalParameters.aspx?type=1. Accessed 5 June 2020.

24. Centralna Ewidencja i Informacja o Działalności Gospodarczej. https://prod.ceidg.gov.pl/CEIDG .CMS.ENGINE/?D;f124ce8a-3e72-4588-8380-63e8ad33621f . Accessed 5 June 2020.

25. Centralna Ewidencja i Informacja o Działalności Gospodarczej. https://prod.ceidg.gov.pl/ceidg.cms. engine/ . Accessed 5 June 2020.

26. Centralna Ewidencja i Informacja o Działalności Gospodarczej (Help Center). https://prod.ceidg .gov.pl/ceidg.cms.engine/?D;7b748944-269b-4581-b27b-0144264fac7e. Accessed 5 June 2020.

27. Elektroniczna Platforma Usług Administracji Publicznej. https://epuap.gov.pl/wps/portal. Accessed 5 June 2020 .

28. Obywatel.gov.pl. https://obywatel.gov.p1/. Accessed 5 June 2020.

29. Obywatel.gov.pl. https://obywatel.gov.pl/o-serwisie. Accessed 5 June 2020. 
30. Obywatel.gov.pl. https://www.gov.pl/web/gov/sprawdz-autobus. Accessed 5 June 2020.

31. Punkt kontaktowy. https://www.biznes.gov.pl/en/firma/doing-business-in-poland/types-of-econo mic-activity-in-poland/the-european-company-basic-information. Accessed 5 June 2020.

32. Punkt kontaktowy. https://www.biznes.gov.pl/glos-przedsiebiorcy. Accessed 5 June 2020.

33. Punkt kontaktowy. https://www.biznes.gov.pl/pl. Accessed 5 June 2020.

34. Punkt kontaktowy. https://www.biznes.gov.pl/pl/firma/zakladanie-firmy. Accessed 5 June 2020.

35. Punkt kontaktowy. https://www.biznes.gov.pl/przedsiebiorcy/. Accessed 5 June 2020.

Publisher's Note Springer Nature remains neutral with regard to jurisdictional claims in published maps and institutional affiliations. 